\title{
ĐặC ĐIỂM LÂM SÀNG VÀ VI SINH GÂY BỆNH TRÊN BỂNH NHÂN ĐợT CẤP BÊ̂NH PHỔI TẮC NGHẼN MẬN TÍNH NHẬP VIỆN
}

Nguyễn Văn Thành ${ }^{(1)}$, Đinh Ngọc Sỹ ${ }^{2}$, Trần Văn Ngọc ${ }^{3}$, Phạm Hùng Vân ${ }^{4}$, Cao Thị Mỹ Thúy ${ }^{5}$, Nguyễn Đình Duy ${ }^{6}$, Lê Thị Thu Hương ${ }^{7}$

\section{TÓM TẮT}

Đặt vấn đề và mục tiêu: Có rất ít nghiên cứu và ở Việt nam chưa có nghiên cứu nào về đăc điềm quản lý và điều trị trước đợt cấp, kiểu hình và vi sinh gây bênh trên bềnh nhân đợt cấp bệnh phổi tắc nghẽn mạn tính (COPD) nhập viện không ICU. Nghiên cứu được thực hiên nhằm xác định các khoảng trống thực hành hướng tới giảm đợt cấp và tăng hiệu quả điều trị đợt cấp COPD. Bênh nhân và phương pháp: Nghiên cứu mô tả, cắt ngang, theo dõi dọc, đa trung tâm thực hiên trên bênh nhân được chẩn đoán đợt cấp COPD theo protocol nghiên cứu, nhập viện điều trị không ICU. Kết quả và bàn luấn: Có 120 bệnh nhân được phân tích. Đa số bệnh nhân đã được quản lý, có đo chức năng hô hấp $(73,3 \%)$ và được theo dõi điều trị $(75,8 \%)$ nhưng đa số vẫn còn triệu chứng khó thở trước đợt cấp mức độ trung bình-năng. Tỷ lệ bệnh nhân có nhiều đợt cấp và đợt cấp nhập viện cao. Chỉ định điều trị và theo dõi đợt cấp ngay tại phòng cấp cứu để đánh giá và quyết định nhập viện chưa hợp lý. Có sự khác biêt giữa các site về chỉ định kháng sinh (nhất là tỷ lệ bệnh nhân không điều trị kháng sinh và kết hợp kháng sinh ngay từ đâu), sử dụng thuốc dãn phế quản tác dụng dài và CRS dang hít. 95\% các trường hợp điều trị có kết quả tốt với thời gian điều trị trung bình trong bệnh viện là 6,9 ngày, dao động từ 2-35 ngày. Xét nghiệm vi sinh kết hợp giữa cây và PCR cho thấy đa tác nhân vi sinh là chủ yếu, trên $50 \%$ các trường hợp có kết hợp virus với vi khuẩn. Sự hiện diện của S.pneumoniae, H.influenzae là nhiều nhất. Có hiện diện của P.aeruginosa với tỷ lệ thấp. Dưới tác động của điều trị, thở co kéo, $\mathrm{SpO}_{2}$ và $\mathrm{CRP}$ là các marker cải thiện nhanh. Có tương quan thuận giữa hình ảnh Xquang gợi ý khí phế thũng và không tăng BCĐNTT máu, giữa nhiễm virus với đồng nhiễm vi khuẩn, nhất là S.pneumoniae và giữa tăng CRP $\geq 30 \mathrm{mg} / \mathrm{L}$ với đổi kháng sinh trong quá trình điêu trị. Kết luâan: Còn nhiều khoảng trống trong quản lý và điều trị COPD để làm giảm đợt cấp cũng như trong xử trí đợt cấp COPD nhập viện.

\footnotetext{
${ }^{1}$ Trường Đại học Y - Dược Cần Thơ

${ }^{2}$ Tông hội Y học Việt Nam

${ }^{3}$ Hội Phổi Việt Nam

${ }^{4}$ Hội Vi sinh lâm sàng Tp. Hồ Chí Minh

${ }^{5}$ Bềnh viên Đa khoa Trung ương Cần Thơ

${ }^{6}$ Bệnh viện Phạm Ngọc Thạch Tp. Hồ Chí Minh

'Bệnh viện Nhân Dân Gia Định Tp. Hồ Chí Minh

Chịu trách nhiệm chính: Nguyễn Văn Thành

Email: drthanhbk@gmail.com

Ngày nhận bài: 18.2.2021

Ngày phản biện khoa học: 29.3.2021

Ngày duyệt bài: 8.4.2021
}

\section{SUMMARY \\ CLINICAL AND PATHOGENIC MICROBIOLOGICAL CHARACTERISTICS ON THE HOSPITALISED PATIENTS WITH ACUTE EXACERBATION OF CHRONIC OBSTRUCTIVE PULMONARY DISEASE}

Problems and goals: There are very few studies and in Vietnam there are no studies on the characteristics of pre-exacerbation management and treatment, phenotype and pathogenic microorganisms in patients with acute exacerbation of chronic obstructive pulmonary disease of non-ICU hospitalization. Research was conducted to identify practical gaps towards reducing exacerbations and increasing efficacy in treatment of COPD exacerbations. Patients and Methods: Descriptive, cross-sectional, longitudinal, multicenter studies performed on patients diagnosed with COPD acute exacerbations according to the study protocol, hospitalized for non-ICU treatment. Results nad discussions: 120 patients were analyzed. The majority of patients were managed, had pulmonary function measurements $(73.3 \%)$ and followed-up for treatment (75.8\%), but the majority still had pre-exacerbation moderate-severe dyspnea. The proportion of patients with frequent exacerbations and hospitalised exacerbations was high. Indication of treatment and follow-up of exacerbations in the emergency room to evaluate and decide hospitalization are unreasonable. There are differences between sites in antibiotic indications (especially the proportion of patients who did not receive an antibiotic and initially combined antibiotics), using long-acting bronchodilators, and inhaled CRS. 95\% of treatment cases have good results with an average time of treatment in the hospital is 6.9 days, ranging from 2 to 35 days. Microbiological assay results combining culture and PCR showed that multiple microbial agents is dominant, in over $50 \%$ of cases there is a combination of virus with bacteria. The presence of S.pneumoniae, $\mathrm{H}$.influenzae is the most. Presence of P.aeruginosa at a low rate. Under the action of treatment, using respiratory accessory muscles, $\mathrm{SpO}_{2}$ and $\mathrm{CRP}$ are markers of rapid improvement. There is a positive correlation between X-ray images suggesting emphysema and no increase in blood cells, between viral infection with bacterial co-infection, especially S.pneumoniae and between increased CRP $\geq 30 \mathrm{mg} / \mathrm{L}$ and antibiotic exchange during treatment. Conclusion: There are still the gaps in COPD management and treatment to reduce exacerbations as well as manage COPD exacerbations in hospital.

Tư khóa: Đớt cấp COPD (Acute exacerbation of COPD), Nhiễm trùng hô hấp dưới (Lower respiratory tract infection), Vi sinh gây bệnh (Microbial pathogens). 


\section{I. ĐĂT VẤN ĐỀ}

Bệnh phổi tắc nghẽn mạn tính (COPD) là bệnh lý hô hấp phổ biến. Ở phạm vi toàn cầu, tỷ lệ mắc khoảng $10 \%$ và đang có tác động tới sức khỏe trên khoảng 380 triệu người, con số này ở Việt Nam khoảng 4 triệu người ở độ tuổi trên 40.

Bệnh nhân COPD thường có nguy cơ đợt cấp (AECOPD). Đợt cấp COPD được định nghĩa là tình trạng nặng lên của triệu chứng hô hấp một cách cấp tính cần thay đổi trị liệu để kiểm soát. Triệu chứng của AECOPD có thể biểu hiện từ nhẹ tới nặng và thậm trí gây tử vong. Có một phân nhóm bệnh nhẩn có kiểu hình (phenotype) nhiều đớt cấp. $A E C O P D$ làm cho tiến trình của COPD xấu đi nhanh, tăng nguy cơ tử vong sớm, chất lượng sống của người bệnh giảm, tăng chi phí điểu trị. Đợt cấp COPD chiếm trên $50 \%$ tổng chi phí điều trị trong COPD. Hiên nay ở các khoa lâm sàng hô hấp trong bệnh viện, số bệnh nhân đợt cấp COPD chiếm khồng dưới 30\% trên tổng số giường bệnh. Bên cạnh đó, chất lượng quản lý COPD ở giai đoạn ổn đinh không tốt là một trong nguyên nhân chính dấn đến nhiều đợt cấp và nhiều đợt cấp nặng nhập viện ${ }^{(1,2)}$.

Với những tác động tiêu cực như trên, trong tình hình thực tế Viềt Nam, AECOPD thực sư rất cần được nghiên cứu, phân tích. Những vấn đề trọng tầm bao gồm: Đặc điểm quản lý và điều trị ở giai đoạn ổn định, đặc điểm bệnh lý đợt cấp, hiệu quả tác động điều trị trong đợt cấp. Trên cơ sở đó, các đề xuất nhằm cải thiện chất lượng điều trị đợt cấp và làm giảm đợt cấp trên bệnh nhân COPD nói chung và trên bệnh nhân COPD kiểu hình nhiều đợt cấp nói riêng là rất cấp thiết.

Nghiên cứu thực hiện với các mục tiêu sau: $i$ ) Xác định đặc điểm quản lý và điều trị của bênh nhân trước đợt cấp, ii) Xác định đặc điểm bệnh lý theo mức độ nặng và kiếu hinh đợt câp, iii) Đánh giá hiệu quả điều trị đợt cấp quy ước (conventional treatment) và iv) Xác định đặc điểm vi sinh gây bệnh.

\section{II. ĐỐI TƯợNG VÀ PHƯƠNG PHÁP NGHIÊN CỨU Thiết kế nghiên cứu:}

- Mô tả, cắt ngang, theo dõi dọc, đa trung tâm, thực hiện ở trong bệnh viện.

- Các site tham gia nghiên cứu: Khoa Hô hấp BVĐKTW Cần Thơ, Khoa Hô hấp BVND Gia định, Khoa Bệnh phổi tắc nghẽn BV Phạm Ngọc Thạch. Xét nghiệm Vi sinh tại Phòng Xét nghiệm Vi sinh Công ty Nam Khoa Biotek.

\section{Bệnh nhân:}

- Chẩn đoán COPD dựa vào tiêu chuẩn chẩn đoán COPD của GOLD guideline 2020 và Biên bản đồng thuận chuyên gia: "GOLD 2019 và quan điểm của Hội Phổi Việt Nam trong thực hành quản lý và điểu trị COPD tại Việt Nam" (Hội Phổi Viêt Nam 2019). Chẩn đoán đớt cấp COPD theo tiều chuẩn GOLD 2020 và Biên bản đồng thuận chuyên gia: "Đợt cấp COPD: Từ bản chất tới thực hành" (Tổng Hội Y học Việt Nam 2020).

Chẩn đoán vi sinh gây bệnh: Thực hiện bằng cả 2 phương pháp: Cấy đàm thường quy và realtime PCR định lượng trên bệnh phẩm đờm.

Phân tích thống kê: Dựa trên các test phân tích thống kê mô tả (descriptive), phân tích tương quan (correlate, compare means và regression). Sự khác biệt được xem là có ý nghĩa khi $p<0,05$. Các phân tích được thực hiện bằng phần mềm SPSS 20.0 (SPSS, Chicago, IL, USA).

\section{KẾT QUẢ NGHIÊN CỨU VÀ BÀN LUÂ̂N}

3.1. Đặc điểm bệnh nhân: Có 120 trường hợp từ 3 site vào nghiên cứu. Đặc điểm dân số học của bệnh nhân là không khác nhau giữa các site, chủ yếu là nam giới (chiếm 95\%), với tuổi trung bình là 68,3 và đa số $(69,2 \%)$ là trên 65 tuổi. Hầu hết bệnh nhân đã được quản lý, có đo chức năng hô hấp $(\mathrm{CNHH})(73,3 \%)$ và được theo dõi điêu trị $(75,8 \%)$.

Có $64,2 \%$ bệnh nhân vẫn còn khó thở mức độ trung bình-năang trước khi vào đợt cấp lần này và 83,9\% bệnh nhân có nhiều đợt cấp. Đặc biệt, trung bình có 1,5 đợt cấp cần nhập viện / bệnh nhân trong 12 tháng trước. Lý do nhập viện là khó thở chiếm tuyệt đại đa số $(98,3 \%)$ và $80 \%$ bệnh nhân đến thẳng không qua chuyển tuyến.

Ghi nhận triệu chứng lâm sàng khi vào cấp cứu cho thây $100 \%$ bệnh nhân không giảm tri giác. Số bệnh nhân có mạch $\geq 110 \mathrm{l} / \mathrm{p}$ chiếm $32,8 \%$, nhịp thở $\geq 30 \mathrm{l} / \mathrm{p}$ chiếm $5,0 \%$ và $\mathrm{SpO}_{2}$ $<90 \%$ thở khí phòng chiếm $59,2 \%$. Chỉ có 1 $(0.8 \%)$ bệnh nhân có ghi nhận rung nhĩ.

Ghi nhận ở các điểm cắt có ý nghĩa xác định bản chất viêm do nhiễm trùng như $\mathrm{BCETT}$ $\geq 11.000 / \mathrm{mm}^{3}$, tỷ lệ BCĐNTT/BCLP $\geq 4,5$, CRP $\geq 30 \mathrm{mg} / \mathrm{L}$, tỷ lệ BCAT trên tổng số bạch cầu máu $\geq 2 \%$, hình ảnh xquang ngực có hay không gợi ý khí phế thũng, cho thấy có sự khác nhau rất rõ giữa các bệnh nhân và giữa các site, thể hiện bằng giá trị cao của SD đối với các trị số trung bình và sự khác biệt về tỷ lệ \% giữa các site.

Đặc điểm điều trị cơ bản (kháng sinh, thuốc dãn phế quản, corticosteroid) có thể nhận định chung là khá tương đồng về đặc điểm có hay không chỉ định thuốc trên từng bệnh nhân và ở cả 3 site. Phân tích cụ thể hơn cho thấy chỉ định kháng sinh, chỉ định corticosteroid dạng khí dung 
khác nhau có ý nghĩa giữa các site. Về điều trị, có thể có một số nhận xét khái quát như sau:

- Chỉ định kháng sinh: Trong chỉ định kháng sinh ban đầu, có khoảng $25 \%$ số bệnh nhân không sử dụng kháng sinh, $50 \%$ số bềnh nhân sử dụng đơn kháng sinh và $25 \%$ số bệnh nhân chỉ định kháng sinh kết hợp. Trong chỉ định đơn kháng sinh, kháng sinh nhóm 1 (amoxicillin/kháng betalactamase) là nhiêu nhất (chiếm tỷ lệ 30\% trên tổng số bệnh nhân), tiếp theo là kháng sinh nhóm 2 (cephalosporin thế hệ II, III) (chiếm tỷ lệ 15,8\% trên tổng số bệnh nhân). Mặc dù có sự khác biêtt có ý nghĩa trong cách chỉ định kháng sinh giữa các site ở cả hai thời điểm điều trị ban đầu và điều trị sau 72 giờ cho đến kết thúc nhưng tỷ lệ bệnh nhân cân đổi kháng sinh trong quá trình điều trị lại không có sự khác biệt có ý nghĩa.

- Chỉ định thuốc dãn phế quản: Tuyệt đại đa số $(96,7 \%)$ bệnh nhân được chỉ định thuốc dãn phế quản dang khí dung. Không có trường hợp nào được chỉ định thuốc dãn phế quản bằng đường MDI qua spacer. Có một tỷ lệ thấp $(6,7 \%)$ bệnh nhân được chỉ định kết hợp thuốc dãn phế quản tác dung dài.

- Chỉ định thuốc corticosteroid: Cũng tuyệt đại đa số bệnh nhân được sử dụng corticosteroid đường tĩnh mach $(82,5 \%)$. Tỷ lệ bênh nhân sử dưng thuốc đường uống thấp $(12,5 \%)$. Có 30,5\% bệnh nhân điêu trị corticosteroid dạng khí dung. Hẩu như tất cả (35/36 bệnh nhân) sử dụng corticosteroid khí dung đồng thời với sử dung corticosteroid toàn thân.

- Ngày điều trị trung bình không khác biệt giữa các site, trung bình 6,9 ngày, thấp nhất là 2 ngày, cao nhất là 35 ngày.

Nhìn một cách tổng quát, đợt cấp COPD nhập viện chưa được tiếp cận điều trị theo kiểu hình (phenotype) như nhiêu y văn gần đây nhấn mạnh ${ }^{(3)}$.

Vi sinh phân lập được cớ bản là phối hợp đa tác nhân (vi khuẩn kết hợp vi khuẩn, vi khuẩn kết hợp virus) với tỷ lệ khoảng từ $60 \%$ đến $70 \%$. Trong các vi khuẩn phân lập được, sự hiên diên của S.pneumoniae là nhiều nhất $(55.8 \%)$, tiếp đến là H.influenzae (25.2\%). P.aeruginosa chỉ gặp ở $11.8 \%$ các trường hợp.

3.2. Diễn biến của các marker lâm sàng và xét nghiệm dưới tác động của điều trị: Nghiên cứu đã thực hiện ghi nhận các dấu hiệu lâm sàng (mạch, nhịp thở, thở co kéo, $\mathrm{SpO}_{2}$ ở 4 thời điểm: khi vào cấp cứu (lần 1 ), khi vào khoa (lần 2), trong 72 giờ tại khoa (lấn 3 ) và trong thời gian sau 72 giờ đến khi kết thúc (lần 4). Diễn biến các marker không khác nhau giữa các site. Mach và nhip thở diễn biến châ̂m. Các marker khác như $\mathrm{SpO}_{2}$, thở co kéo thay đổi nhanh dưới tác đông của điều trị. Số lượng bach câu đa nhân trung tính thay đổi chậm, kể cả khi số lượng BCĐNTT tăng $\geq 11.000 / \mathrm{mm}^{3}$. CRP là marker giảm ổn định trong theo dõi và nhanh, nhất là với những trường hợp tăng $\geq 30 \mathrm{mg} / \mathrm{L}$ (hình 1).

3.3. Phân tích tương quan giữa môt số yếu tố lâm sàng, cân lâm sàng và kêt cực điêuu trị: Phân tích kiểu hình đợt cấp COPD trển cơ sở những thông tin có được bằng cách xác định tương quan: i) Giữa các marker cận lâm sàng, ii) Giữa các marker cận lâm sàng và kết quả xét nghiêm vi trùng học, iii) Giữa kết quả vi trùng học với đắc điểm nhiều đợt cấp, iv) Giữa nhiễm virus với đồng nhiễm vi khuẩn, v) Giữa tăng BCAT với nhiễm virus và với ngày điều trị, vi) Giữa các đăc điểm lâm sàng với các kết cục điêu trị, và vii) Giữa chỉ định kháng sinh ban đầu với ngày điều trị. Kết quả như sau: Có tương quan thuận có ý nghĩa giữa hình ảnh Xquang ngực gợi ý khí phế thũng với không tăng $B C Đ N T T \geq 11.000 / \mathrm{mm}^{3}$ khi vào khoa $(\mathrm{p}=0,001)$. Có tương quan thuânn có ý nghĩa giữa đồng nhiễm virus và đồng nhiễm S.pneumoniae $(p=0,03)$ và với các vi khuẩn khác nhóm 1 và 3 $(p=0,01)$. CRP ở điểm cắt $\geq 30 \mathrm{mg} / \mathrm{L}$ có mối tương quan thuận có ý nghĩa với việc thay đổi điều trị kháng sinh sau 72 giờ điều trị $(p=0,007)$. Phân tích thêm cho thấy khi CRP tăng $\geq 30 \mathrm{mg} / \mathrm{L}$ kèm theo tăng tỷ lê BCĐNTT/BCLP $\geq 4,5$ khả năng đổi kháng sinh tăng với OR 2.86 (CI 95\% $1.2-7.2, p=0,02)$.

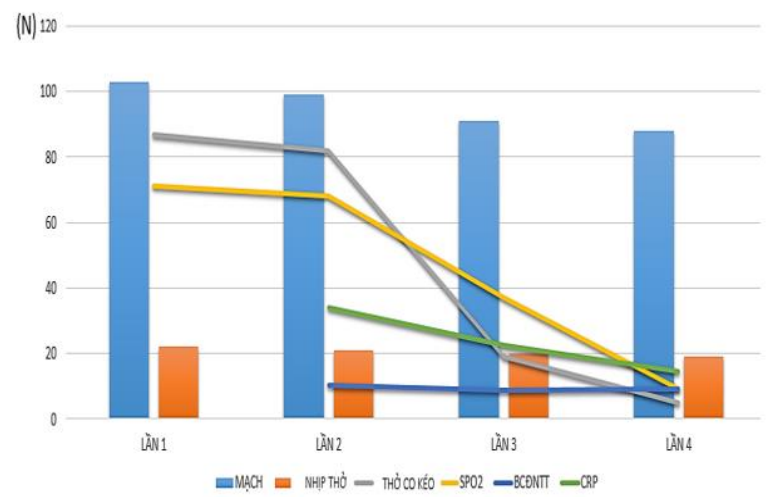

Hình 1. Diễn biến các marker lâm sàng và cận lâm sàng dưới điều trị

Qua phân tích 120 trường hợp đợt cấp nhâp viện không ICU cho thây hầu hết bệnh nhẩn đang được quản lý và điều trị chuyên khoa nhưng đa số vẫn còn triệu chứng khó thở mức 
độ trung bình-nặng. Tỷ lệ bệnh nhân có nhiều đợt cấp và đợt cấp nhập viện cao. Việc chỉ định điêu trị và theo dõi đợt cấp ngay tại phòng cấp cứu để đánh giá và quyết định nhập viện chưa hợp lý $(4,5)$. Có sự khác biệt giữa các site về chỉ định kháng sinh (nhất là tỳ lệ bệnh nhân không điều trị kháng sinh và kết hợp kháng sinh ngay từ đầu), sử dụng thuốc dãn phế quản tác dụng dài và corticosteroid dạng hít. $95 \%$ các trường hợp điều trị có kết quả tốt với thời gian điều trị trung bình trong bệnh viện là 6,9 ngày, dao động từ 2-35 ngày. Xét nghiệm vi sinh kết hợp giữa cấy và $P C R$ cho thấy hình ảnh đa tác nhân vi sinh là chủ yếu, trên $50 \%$ các trường hợp có kết hợp virus với vi khuẩn. Sự hiện diện của S.pneumoniae, H.influenzae là nhiều nhất. Có hiện diện của P.aeruginosa với tỷ lệ thấp. Dưới tác động của điều trị, thở co kéo, $\mathrm{SpO}_{2}$ và $\mathrm{CRP}$ là các marker cải thiện nhanh. Có tương quan thuận giữa hình ảnh Xquang gợi ý khí phế thũng và không tăng BCĐNTT máu, giữa nhiễm virus với đồng nhiễm vi khuẩn, nhất là S.pneumoniae và giữa tăng $C R P \geq 30 \mathrm{mg} / \mathrm{L}$ với đổi kháng sinh trong quá trình điều trị. Trên cơ sở này, nghiên cứu đề xuất sơ đồ xử trí hướng tới giảm đợt cấp và thực hành hợp lý đợt cấp COPD như hình 2.

\section{ĐƠT CÃ̃ VÀO CÃP CƯU}

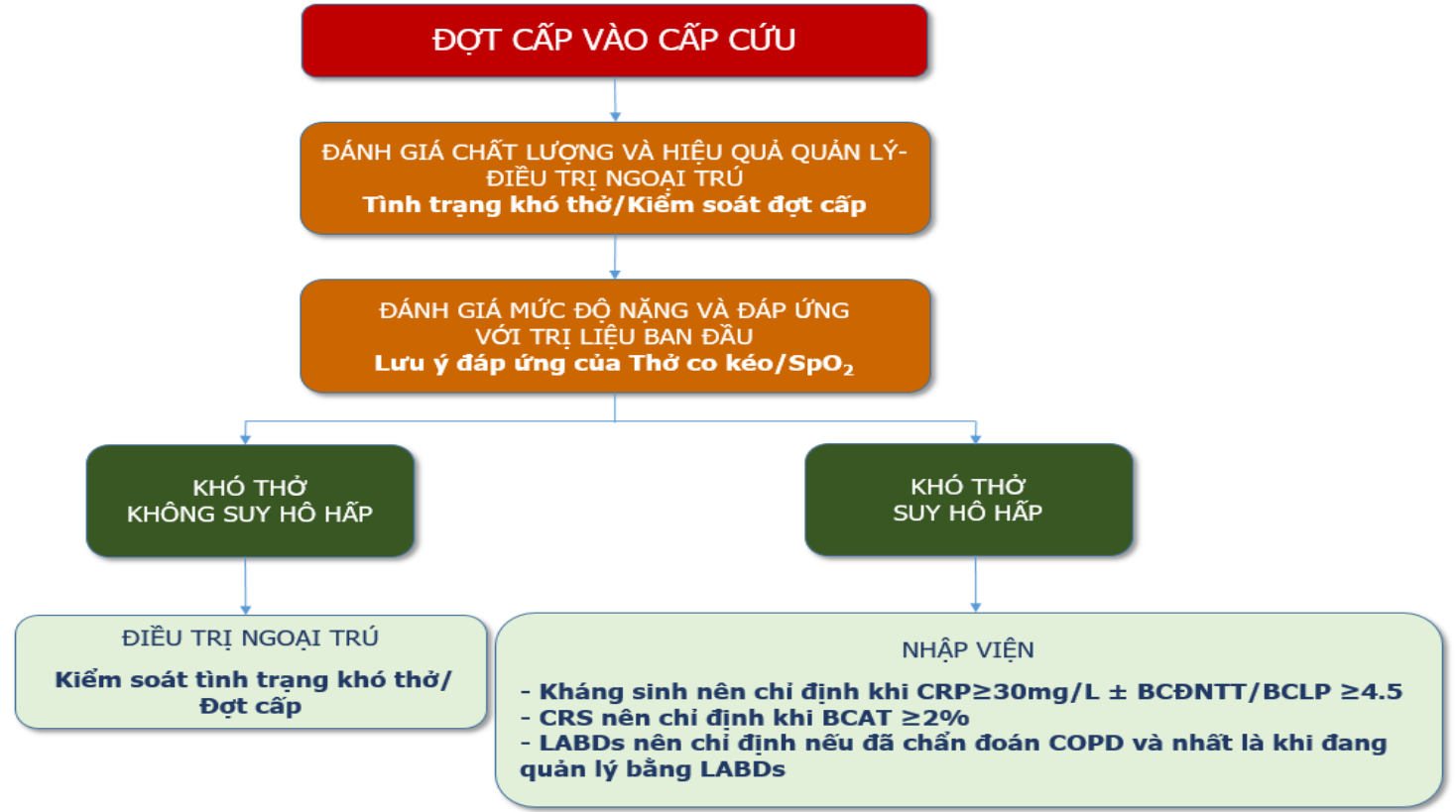

Hình 2. Sơ đồ thực hành xử trí đợt cấp COPD đến khám cấp cứu tại các bệnh viện

\section{KẾT LUẦN}

Trên cơ sở phân tích 120 trường hợp đợt cấp nhập viện không ICU nghiên cứu đã ghi nhận còn nhiều khoảng trống trong quản lý và điều trị COPD để làm giảm đợt cấp cũng như trong xử trí đợt cấp COPD nhập viện.

Minh bạch: Nghiên cứu nhận tài trợ nghiên cứu từ Công ty cổ phần dược phẩm Imexpharm và Công ty Nam khoa Biotek.

\section{TÀI LIỆ THAM KHẢO}

1. Connors AF, Jr., Dawson NV, Thomas C, et al. Outcomes following acute exacerbation of severe chronic obstructive lung disease. The SUPPORT investigators (Study to Understand Prognoses and Preferences for Outcomes and Risks of Treatments). Am J Respir Crit Care Med. 1996
Oct; $154(4$

$\mathrm{Pt}$

1):959-67.

Doi: 10.1164/ajrccm.154.4.8887592. PMID: 8887592.

2. Seemungal TA, Donaldson GC, Paul EA, et al. Effect of exacerbation on quality of life in patients with chronic obstructive pulmonary disease. Am J Respir Crit Care Med. 1998 May;157(5 Pt 1):1418 22. Doi: 10.1164/ajrccm.157.5.9709032. PMID: 9603117.

3. Aiyuan Zhou, Zijing Zhou, Yiyang Zhao et al. The recent advances of phenotypes in acute exacerbations of COPD. International Journal of COPD 2017:12 1009-1018

4. Celli BR, Barnes PJ. Exacerbations of chronic obstructive pulmonary disease. Eur Respir J. 2007;29(6):1224-38.

5. Crisafulli et al. Management of severe acute exacerbations of COPD: an updated narrative review. Multidisciplinary Respiratory Medicine (2018) $13: 36$ 